
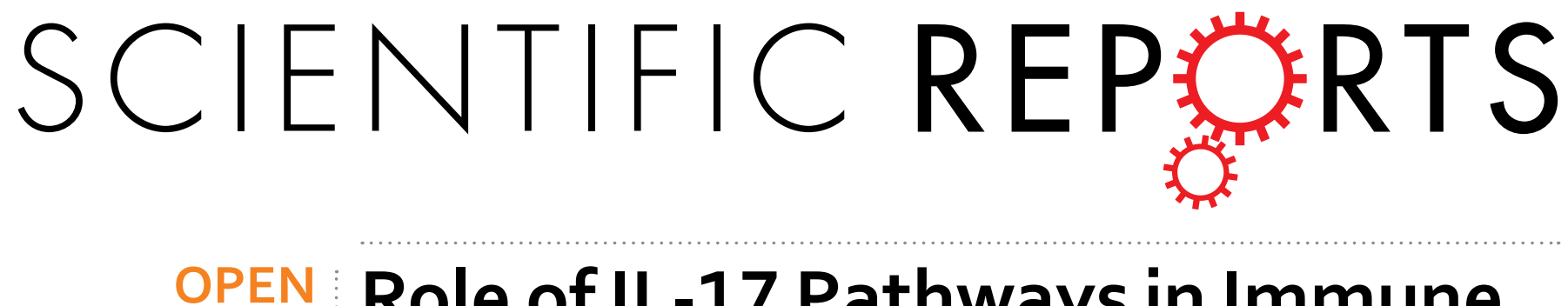

\title{
Role of IL-17 Pathways in Immune Privilege: A RNA Deep Sequencing Analysis of the Mice Testis Exposure \\ to Fluoride
}

Received: 11 May 2016

Accepted: 02 August 2016

Published: 30 August 2016

\author{
Meijun Huo ${ }^{1}$, Haijun $\mathrm{Han}^{1}$, Zilong Sun ${ }^{1}$, Zhaojing Lu ${ }^{1}$, XingleiYao ${ }^{1}$, Shaolin Wang ${ }^{2}$ \& \\ Jundong Wang ${ }^{1}$
}

We sequenced RNA transcripts from the testicles of healthy male mice, divided into a control group with distilled water and two experimental groups with 50 and $100 \mathrm{mg} / \mathrm{l} \mathrm{NaF}$ in drinking water for 56 days. Bowtie/Tophat were used to align 50-bp paired-end reads into transcripts, Cufflinks to measure the relative abundance of each transcript and IPA to analyze RNA-Sequencing data. In the $100 \mathrm{mg} / \mathrm{l} \mathrm{NaF}$ treated group, four pathways related to IL-17, TGF- $\beta$ and other cellular growth factor pathways were overexpressed. The mRNA expression of IL-17RA, IL-17RC, MAP2K1, MAP2K2, MAP2K3 and MAPKAPK2, monitored by qRT-PCR, increased remarkably in the $100 \mathrm{mg} / \mathrm{L} \mathrm{NaF}$ group and coincided with the result of RNA-Sequencing. Fluoride exposure could disrupt spermatogenesis and testicles in male mice by influencing many signaling pathways and genes, which work on the immune signal transduction and cellular metabolism. The high expression of the IL-17 signal pathway was a response to the invasion of the testicular immune system due to extracellular fluoride. The PI3-kinase/AKT, MAPKs and the cytokines in TGF- $\beta$ family were contributed to control the IL-17 pathway activation and maintain the immune privilege and spermatogenesis. All the findings provided new ideas for further molecular researches of fluorosis on the reproduction and immune response mechanism.

Epidemiological investigations showed male infertility, low birth rates and abnormalities in sperm morphology, oligospermia and azoospermia occurring in areas with a high fluoride content ${ }^{1-7}$. Even in 2008 and 2009, Bruce Spittle, Managing Editor of the Journal Fluoride, published two articles in two consecutive years and emphatically stated the adverse effects of fluoride on male reproductive function ${ }^{7,8}$. Further studies in animals indicated a negative impact of fluoride ingestion on testicular histology, the structure of hypothalamus-pituitary-testicular and sperm quality ${ }^{9}$, including: sperm malformation ${ }^{7,10-12}$, sperm density, motility and activity ${ }^{8,13,14}$, spermchemotaxis $^{15}$, sperm hyperactivation, capacitation, acrosome reaction and fertilizing ability ${ }^{16}$.

But how does fluoride affect male reproductive function with regard to the mechanism? It has been widely reported in the male reproductive systems that spermatogenesis was formed in testes and regulated by the hormone testosterone, cytokines and gene and protein expressions ${ }^{17,18}$. Meanwhile, our previous studies and many hazard identification studies also revealed that high doses of fluoride in animals affect potentially sensitive reproductive-tract targets and pathways, such as the reduction of antioxidant defenses, the enhancement of oxidative stress, and changes in the testicular cell cycle ${ }^{19-22}$. Overall, a number of studies have indicated fluoride exposure disrupts testicular development, but most of them focused on pathological observation and a limited number of genes so that up to now the specific molecular mechanisms of fluoride-induced spermatogenesis dysfunction were not clear.

Due to the complexity of molecular mechanisms, high throughput methods are quite necessary and playing more and more important roles in the research of toxicology. Moreover, the matured transcriptome sequencing (RNA-Seq) platforms have been successfully applied to the detection of gene fusions in cancer ${ }^{23}$, the analysis

\footnotetext{
${ }^{1}$ Shanxi Key Lab of Environ-Veterinary Science, College of Animal Science and Technology, Shanxi Agricultural University, Taigu, Shanxi, 030801, People's Republic of China. ${ }^{2}$ Beijing Advanced Innovation Center for Food Nutrition and Human Health, College of Veterinary Medicine, China Agriculture University, Beijing, 100193, People's Republic of China. Correspondence and requests for materials should be addressed to S.W. (email: shaolinwang@outlook. com) or J.W. (email: wangjd53@outlook.com)
} 
of vaccinia virus and host cell transcriptomes ${ }^{24}$ and the quantitative calculation of the abundance of expressed genes among the tissue transcriptome sequence data ${ }^{25}$. Thus, the deep RNA-Seq was applied to focus on genes and biological pathways affected by fluoride using and experimental validation to uncover the molecular basis of reproduction and sperm metabolism disorder. Delineating the overall gene expression profile in the testicles of experimental fluorosis mice will help to deeply identify the mechanisms involved in reproductive toxicity and other pathological disorders associated with fluoride.

\section{Methods}

Animals. Sixty adult male Kunming mice (aged 8 weeks, 25-26 g b.w.) were purchased from the Experimental Animal Center of Shanxi Medical University (Taiyuan, China), housed in standard plastic cages, maintained in a temperature-controlled environment $\left(22-25^{\circ} \mathrm{C}\right)$ with a $12 \mathrm{~h}$ light/dark cycle and fed a standard mouse diet and water ad libitum. After one-week acclimation, these mice were divided randomly into three groups of 20 each: a control group, which drank distilled water, and other two treatment groups, which received 50 and $100 \mathrm{mg} / \mathrm{l}$ $\mathrm{NaF}$ in their drinking water. The doses were chosen on the basis of the previous studies and considered the toxicities of fluoride in the male reproductive system ${ }^{26-28}$. To make sure of more than four spermatogenic cycles in mice (approximately 40 days) ${ }^{13}$, animals were treated with fluoride for 56 days. It's important to note that in our previous research no significant differences were observed in body weight and major organ coefficient (testis/ body weight) compared with the control group after 56 days fluoride exposure ${ }^{9,15}$. Based on that, we can probably rule out the influence of body weight change on the testicular in itself. Meanwhile, the formal study has found the decreased sperm and disorganized spermatogenic cells with the morphological observations of testis, more severely in high F group. And in Sertoli cells, we observed the density of cytoplasm decreased, heterochromatin gathered and mitochondria appeared with numerous vacuoles. All of these provided the support for sequence analysis.

Statement: All experimental procedures were conducted and performed as the policies for animal care and use encompass regulations approved by the Institutional Animal Care and Use Committee of Shanxi Agricultural University, including Animal Welfare Act, Guide for the Care and Use of Laboratory Animals and Guide for the Care and Use of Agricultural Animals in Research and Teaching.

RNA Sample Preparation. All mice were killed by cervical dislocation on the 56th day, testicles were immediately isolated, frozen in liquid nitrogen and stored at $-80^{\circ} \mathrm{C}$ for RNA extraction and gene expression research. Total RNA was extracted from five tissue samples in each group using TRIzol (Invitrogen, Carlsbad, CA, USA) according to the protocol provided by the manufacturer. The quality and purity of total RNA were monitored by Nanodrop ND-2000 spectrophotometer (Nanodrop Technologies Inc., DE, USA) and electrophoresing on a $0.8 \%$ agarose gel (Sigma, St. Louis, MO), respectively.

RNA Deep Sequencing. Based on the recently published papers, RNA deep sequencing was conducted as follows ${ }^{29,30}$. Briefly, the sequencing library of each RNA sample was prepared with the TruSeq RNA Sample Preparation Kit according to the manufacturer's instructions (Illumina, San Diego, CA). The enriched libraries were diluted with elution buffer to a final concentration of $10 \mathrm{nM}$. Each sample (ca. $7 \mathrm{pM}$ concentration) was subjected to 50 cycles of sequencing from both ends by the Illumina Hiseq ${ }^{\mathrm{TM}} 2000$ sequencing technology. Before doing any further analysis, FastQC (http://www.bioinformatics.bbsrc.ac.uk/projects/fastqc/) was applied to perform quality control checks on raw sequence data coming from high throughput sequencing pipelines.

Following deep sequencing analysis of 50-bp length paired-end reads, Bowtie and Tophat were used to align the reads into transcripts based on the Mouse Reference Genome (ftp://ftp.cbcb.umd.edu/pub/data/bowtie indexes/m_musculus_ncbi37_c.ebwt.zip). To measure the relative abundance of each transcript, the resulting aligned reads were analyzed with Cufflinks suite (http://cufflinks.cbcb.umd.edu). Expression of each transcript was quantified as the number of reads mapping to a gene divided by the gene length in kilobases and the total number of mapped reads in millions, and designated as fragments per kilobase of exon per million fragments mapped (FPKM).

Gene Annotation and Expression Profiling Analysis. The Ensembl Transcript ID was used as the primary identifier for all analyses. When multiple splice variants existed, all of them were selected. In generating the FPKM distributions of intergenic regions, regions with a distance of at least $10 \mathrm{~kb}$ from any RefSeqor Ensembl gene were selected. The annotation information corresponding to each Ensembl Transcript ID was retrieved from the Ensembl database via BioMart (http://www.biomart.org/biomart/martview).

For each fluoride concentration of interest, all the transcripts were pulled from the file generated by Cufflinks. The measurements with RPKM values close to zero (approximately $5 \%$ of the total) were discarded. The RPKM values were logarithmically transformed to base 2 , and the measurements of each transcript within an experimental group were subjected to outlier detection ${ }^{29,30}$.

Enriched Biochemical Pathways in the Fluorosis Testicle. Ingenuity Pathway Analysis (IPA, Ingenuity System Inc, USA, http://www.ingenuity.com/) were used to alter the significant genes, identify global canonical pathways and dynamically generate biological networks in the testicle of experimental fluorosis mice ${ }^{31,32}$. The core component of IPA is the Ingenuity Pathways Knowledge Base (IPKB), which contains the biological function, interaction, and related information of a curated gene set and more than 330 biochemical pathways ${ }^{31}$. Using the whole gene set of IPKB as the background, the genes with their symbols and the corresponding GenBank accession numbers were uploaded into the IPA with a view to revealing the enriched biochemical pathways ${ }^{29,30}$. All the pathways with one or more genes overlapping the candidate genes were extracted. In IPA, each of the canonical pathway was assigned a $P$ value via Fisher's exact test, which denoted the probability of overlap between the pathway and input genes ${ }^{33}$. Reported significance was defined as $P<0.05$ with a fold change (FC) larger than 1.5. 
A
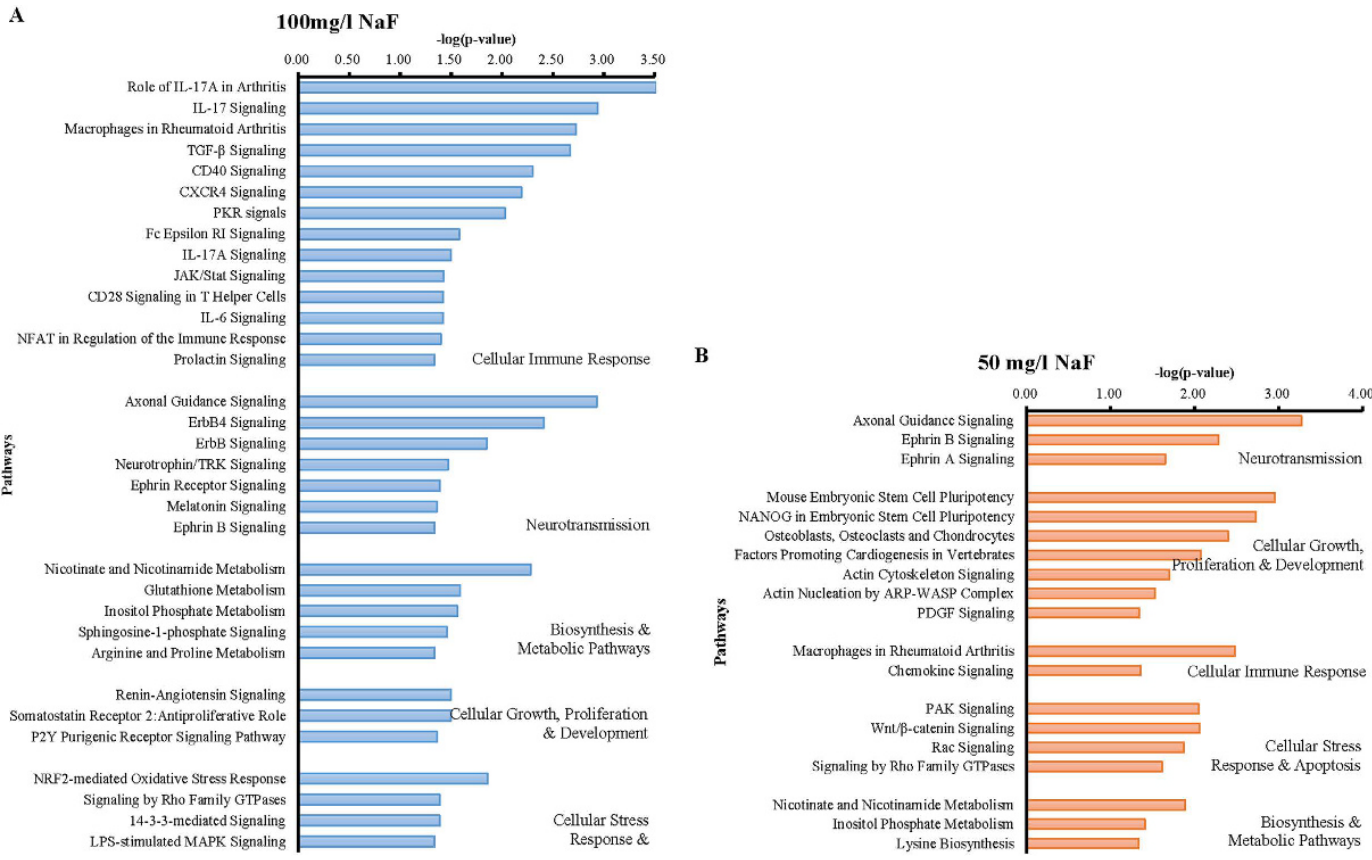

Figure 1. Enriched biochemical pathways altered in the testicle in the $50 \mathrm{mg} / \mathrm{l}$ and $100 \mathrm{mg} / \mathrm{l} \mathrm{NaF}$-treated groups compared to the control groups.

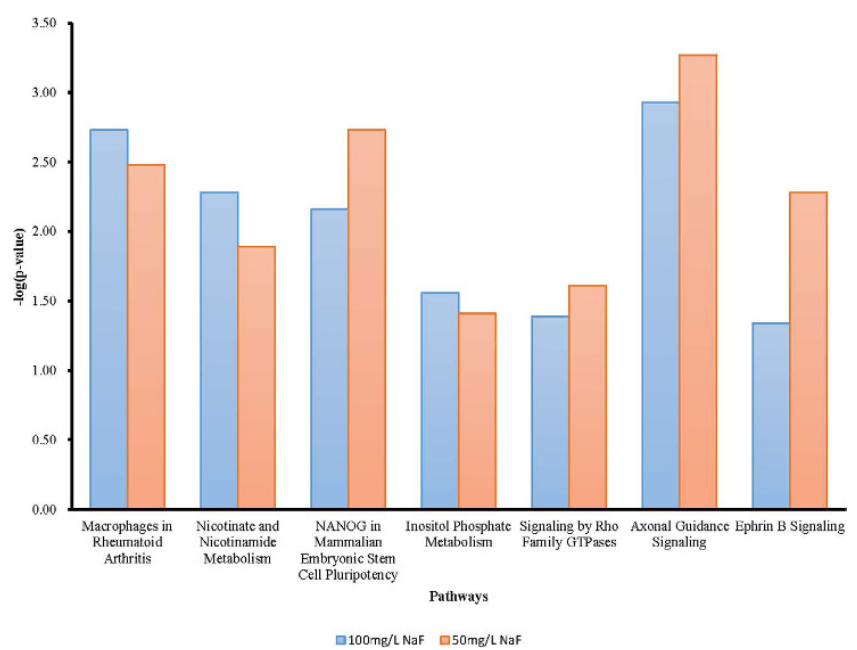

Figure 2. The common significant pathways between the $50 \mathrm{mg} / \mathrm{l}$ and $100 \mathrm{mg} / \mathrm{l} \mathrm{NaF-treated} \mathrm{groups.}$

Quantitative Real Time RT-PCR. Quantitative real-time RT-PCR (qRT-PCR), the traditional quantification method on gene expression, was adopted to further confirm the findings from the RNA-seq analysis. On the basis of the results, we optionally detected several significant genes involved in the IL-17 signaling pathway with the same RNA samples used for RNA-seq analysis, considering they are the only pathways showing differences in the testicle of all the fluorosis groups. These genes and their primers used in the qRT-PCR array were listed in Supplementary Table S1. Primers were designed using Primer Express v. 3.0 software (Applied Biosystem Inc., CA, USA). The qRT-PCR analysis was conducted in a total volume of $10 \mu$ l containing $5 \mu \mathrm{l} 2 \times$ SYBR Premix Ex $\mathrm{Taq}^{\mathrm{TM}}$ (Takara Bio Inc., China), combined with sense and antisense primers $(0.4 \mu \mathrm{l}$, final concentration $250 \mathrm{nM})$, and $1 \mu \mathrm{l}$ diluted cDNA in a 384-well plate using the Applied Biosystems QuantStudio ${ }^{\mathrm{TM}} 7$ Flex Real-Time PCR System (Thermo Fisher Scientific, USA). The conditions for real-time PCR were as follows: after initial denaturation at $95^{\circ} \mathrm{C}$ for $15 \mathrm{~s}, 55 \mathrm{PCR}$ cycles were started with thermo cycling conditions at $95^{\circ} \mathrm{C}$ for $5 \mathrm{~s}, 61^{\circ} \mathrm{C}$ for $15 \mathrm{~s}$, and $72^{\circ} \mathrm{C}$ for $6 \mathrm{~s}$, and then a melting curve analysis was performed to verify the specificity of the PCR product. Every sample was analyzed in triplicate. System software and the $2^{-\Delta \Delta \mathrm{Ct}}$ method were applied to quantitative calculation. 


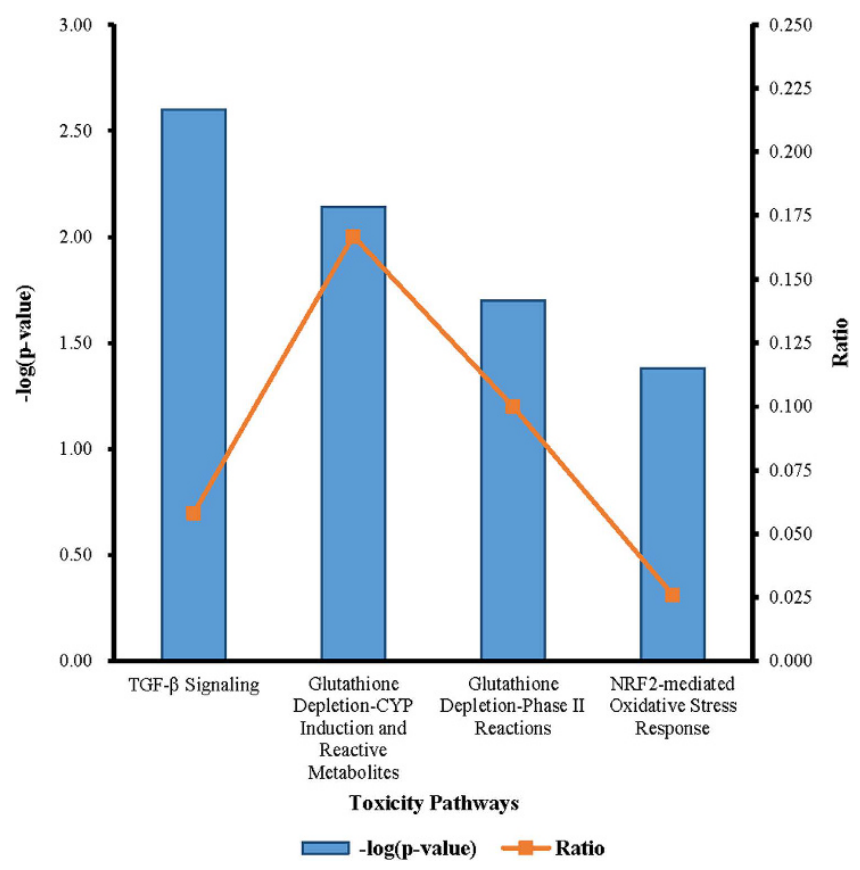

Figure 3. The significant pathways related to toxicology altered in the $100 \mathrm{mg} / \mathrm{l} \mathrm{NaF}$-treated group.

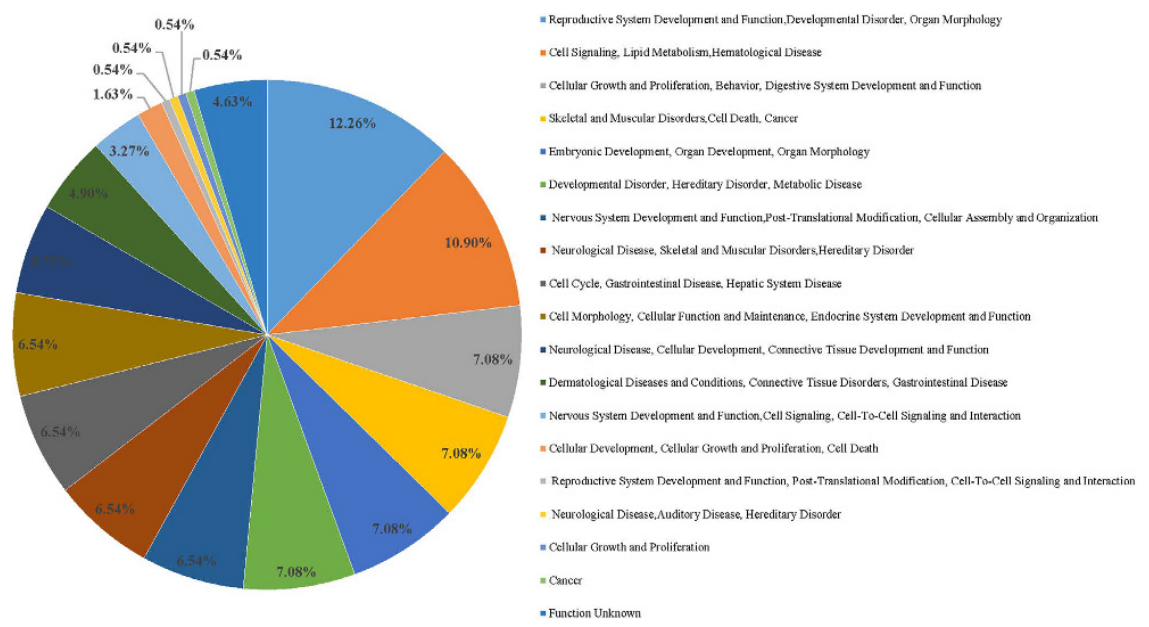

Figure 4. The percentage of different functional genes in all the 367 DEGs screened in the $50 \mathrm{mg} / \mathrm{l}$ and $100 \mathrm{mg} / \mathrm{l} \mathrm{NaF-treated} \mathrm{groups.} \mathrm{It} \mathrm{not} \mathrm{only} \mathrm{presented} \mathrm{the} \mathrm{relationship} \mathrm{among} \mathrm{genes} \mathrm{and} \mathrm{functions,} \mathrm{diseases,} \mathrm{but}$ also describes the important role of genes on the development the reproductive system, nervous system, skeletal and muscular disorders, cell signaling and other metabolic processes.

Data Analysis for qRT-PCR. All data were conducted by GraphPad Prism 5 software (GraphPad Software Inc., San Diego, USA). Statistical analysis was performed by one-way ANOVA and followed by a Tukey's test. All values in the experiment were expressed as mean \pm SEM (standard error of the mean) and values of $P<0.05$ were expressed statistically significant ( $\mathrm{n}=5$ per group).

\section{Result}

Overview of Sequencing Data from RNA-seq Analysis. Sequencing and mapping quality were analyzed using FASTQC. Total sequences among samples ranged from 30 to 37 million reads, with an average of approximately 31 million raw reads per sample. About $23-32 \times 10^{6}$ reads ( $82-84 \%$ of the total raw reads) were uniquely aligned to mouse genome sequence among samples, with an average of $24 \times 10^{6}$ reads per sample. 


\begin{tabular}{|c|c|c|c|c|c|c|c|c|}
\hline$\#$ & Symbol & Matched Pathway & Entrez Gene Name & Ensembl & Fold Change & p-value & Location & Type(s) \\
\hline \multirow{20}{*}{1} & \multirow{20}{*}{ MAP2K2(20) } & Role of IL-17A in Arthritis & \multirow{20}{*}{$\begin{array}{l}\text { mitogen-activated protein } \\
\text { kinase kinase } 2\end{array}$} & \multirow{20}{*}{ ENSMUST00000105331 } & \multirow{20}{*}{2.038} & \multirow{20}{*}{ 4.49E-02 } & \multirow{20}{*}{ Cytoplasm } & \multirow{20}{*}{ kinase } \\
\hline & & IL-17 Signaling & & & & & & \\
\hline & & Axonal Guidance Signaling & & & & & & \\
\hline & & $\begin{array}{l}\text { Role of Macrophages, Fibroblasts } \\
\text { and Endothelial Cells in } \\
\text { Rheumatoid Arthritis }\end{array}$ & & & & & & \\
\hline & & TGF- $\beta$ Signaling & & & & & & \\
\hline & & ErbB4 Signaling & & & & & & \\
\hline & & CD40 Signaling & & & & & & \\
\hline & & $\begin{array}{l}\text { Nicotinate and Nicotinamide } \\
\text { Metabolism }\end{array}$ & & & & & & \\
\hline & & $\begin{array}{l}\text { Glioblastoma Multiforme } \\
\text { Signaling }\end{array}$ & & & & & & \\
\hline & & \begin{tabular}{|l|l|} 
CXCR4 Signaling \\
\end{tabular} & & & & & & \\
\hline & & $\begin{array}{l}\text { Role of NANOG in Mammalian } \\
\text { Embryonic Stem Cell } \\
\text { Pluripotency }\end{array}$ & & & & & & \\
\hline & & Cardiac Hypertrophy Signaling & & & & & & \\
\hline & & $\begin{array}{l}\text { NRF2-mediated Oxidative Stress } \\
\text { Response }\end{array}$ & & & & & & \\
\hline & & ErbB Signaling & & & & & & \\
\hline & & Ovarian Cancer Signaling & & & & & & \\
\hline & & Fc Epsilon RI Signaling & & & & & & \\
\hline & & Inositol Phosphate Metabolism & & & & & & \\
\hline & & $\begin{array}{l}\text { Antiproliferative Role of } \\
\text { Somatostatin Receptor } 3\end{array}$ & & & & & & \\
\hline & & IL-17A Signaling & & & & & & \\
\hline & & Renin-Angiotensin Signaling & & & & & & \\
\hline \multirow{16}{*}{2} & \multirow{16}{*}{ PIK3R1(16) } & Role of IL-17A in Arthritis & \multirow{16}{*}{$\begin{array}{l}\text { phosphoinositide-3-kinase, } \\
\text { regulatory subunit } 6\end{array}$} & \multirow{16}{*}{ ENSMUST00000060441 } & \multirow{16}{*}{2.935} & \multirow{16}{*}{$5.84 \mathrm{E}-03$} & \multirow{16}{*}{ Cytoplasm } & \multirow{16}{*}{ kinase } \\
\hline & & IL-17 Signaling & & & & & & \\
\hline & & Axonal Guidance Signaling & & & & & & \\
\hline & & $\begin{array}{l}\text { Role of Macrophages, Fibroblasts } \\
\text { and Endothelial Cells in } \\
\text { Rheumatoid Arthritis }\end{array}$ & & & & & & \\
\hline & & ErbB4 Signaling & & & & & & \\
\hline & & CD40 Signaling & & & & & & \\
\hline & & $\begin{array}{l}\text { Glioblastoma Multiforme } \\
\text { Signaling }\end{array}$ & & & & & & \\
\hline & & CXCR4 Signaling & & & & & & \\
\hline & & $\begin{array}{l}\text { Role of NANOG in Mammalian } \\
\text { Embryonic Stem Cell } \\
\text { Pluripotency }\end{array}$ & & & & & & \\
\hline & & $\begin{array}{l}\text { NRF2-mediated Oxidative Stress } \\
\text { Response }\end{array}$ & & & & & & \\
\hline & & ErbB Signaling & & & & & & \\
\hline & & Fc Epsilon RI Signaling & & & & & & \\
\hline & & Inositol Phosphate Metabolism & & & & & & \\
\hline & & $\begin{array}{l}\text { Antiproliferative Role of } \\
\text { Somatostatin Receptor } 4\end{array}$ & & & & & & \\
\hline & & IL-17A Signaling & & & & & & \\
\hline & & Renin-Angiotensin Signaling & & & & & & \\
\hline \multirow{6}{*}{3} & \multirow{6}{*}{ MAP2K3(11) } & Role of IL-17A in Arthritis & \multirow{6}{*}{$\begin{array}{l}\text { mitogen-activated protein } \\
\text { kinase kinase } 3\end{array}$} & \multirow{6}{*}{ ENSMUST00000019076 } & \multirow{6}{*}{1.658} & \multirow{6}{*}{$4.12 \mathrm{E}-02$} & \multirow{6}{*}{ Cytoplasm } & \\
\hline & & IL-17 Signaling & & & & & & \\
\hline & & $\begin{array}{l}\text { Role of Macrophages, Fibroblasts } \\
\text { and Endothelial Cells in } \\
\text { Rheumatoid Arthritis } \\
\end{array}$ & & & & & & kinase \\
\hline & & TGF- $\beta$ Signaling & & & & & & \\
\hline & & CD40 Signaling & & & & & & \\
\hline & & $\begin{array}{l}\text { Nicotinate and Nicotinamide } \\
\text { Metabolism }\end{array}$ & & & & & & \\
\hline
\end{tabular}




\begin{tabular}{|c|c|c|c|c|c|c|c|c|}
\hline$\#$ & Symbol & Matched Pathway & Entrez Gene Name & Ensembl & Fold Change & p-value & Location & Type(s) \\
\hline & & $\begin{array}{l}\text { Role of PKR in Interferon } \\
\text { Induction and Antiviral Response }\end{array}$ & & & & & & \\
\hline & & $\begin{array}{l}\text { NRF2-mediated Oxidative Stress } \\
\text { Response }\end{array}$ & & & & & & \\
\hline & & ErbB Signaling & & & & & & \\
\hline & & Fc Epsilon RI Signaling & & & & & & \\
\hline & & Inositol Phosphate Metabolism & & & & & & \\
\hline & \multirow{5}{*}{ WNT6(5) } & Axonal Guidance Signaling & \multirow{5}{*}{$\begin{array}{l}\text { wingless-type MMTV } \\
\text { integration site family, } \\
\text { member } 6\end{array}$} & \multirow{5}{*}{ ENSMUST00000006716 } & \multirow{5}{*}{2.945} & \multirow{5}{*}{ 4.93E-04 } & \multirow{5}{*}{$\begin{array}{l}\text { Extracellular } \\
\text { Space }\end{array}$} & \multirow{5}{*}{ other } \\
\hline & & $\begin{array}{l}\text { Role of Macrophages, Fibroblasts } \\
\text { and Endothelial Cells in } \\
\text { Rheumatoid Arthritis }\end{array}$ & & & & & & \\
\hline 4 & & \begin{tabular}{l|} 
Glioblastoma Multiforme \\
Signaling \\
\end{tabular} & & & & & & \\
\hline & & $\begin{array}{l}\text { Role of NANOG in Mammalian } \\
\text { Embryonic Stem Cell } \\
\text { Pluripotency }\end{array}$ & & & & & & \\
\hline & & $\begin{array}{l}\text { Human Embryonic Stem Cell } \\
\text { Pluripotency }\end{array}$ & & & & & & \\
\hline \multirow{4}{*}{5} & \multirow{4}{*}{ WNT9A(4) } & Axonal Guidance Signaling & \multirow{4}{*}{-} & \multirow{4}{*}{ ENSMUST00000108783 } & \multirow{4}{*}{2.205} & \multirow{4}{*}{ 3.52E-02 } & \multirow{4}{*}{ Other } & \multirow{4}{*}{ other } \\
\hline & & $\begin{array}{l}\text { Role of Macrophages, Fibroblasts } \\
\text { and Endothelial Cells in } \\
\text { Rheumatoid Arthritis }\end{array}$ & & & & & & \\
\hline & & $\begin{array}{l}\text { Glioblastoma Multiforme } \\
\text { Signaling }\end{array}$ & & & & & & \\
\hline & & $\begin{array}{l}\text { Role of NANOG in Mammalian } \\
\text { Embryonic Stem Cell } \\
\text { Pluripotency }\end{array}$ & & & & & & \\
\hline \multirow{4}{*}{6} & \multirow{4}{*}{ WNT10A(4) } & Axonal Guidance Signaling & \multirow{4}{*}{$\begin{array}{l}\text { wingless-type MMTV } \\
\text { integration site family, } \\
\text { member 10A }\end{array}$} & \multirow{4}{*}{ ENSMUST00000006718 } & \multirow{4}{*}{1.973} & \multirow{4}{*}{$2.21 \mathrm{E}-02$} & \multirow{4}{*}{$\begin{array}{l}\text { Extracellular } \\
\text { Space }\end{array}$} & \multirow{4}{*}{ other } \\
\hline & & $\begin{array}{l}\text { Role of Macrophages, Fibroblasts } \\
\text { and Endothelial Cells in } \\
\text { Rheumatoid Arthritis } \\
\end{array}$ & & & & & & \\
\hline & & $\begin{array}{l}\text { Glioblastoma Multiforme } \\
\text { Signaling }\end{array}$ & & & & & & \\
\hline & & $\begin{array}{l}\text { Role of NANOG in Mammalian } \\
\text { Embryonic Stem Cell } \\
\text { Pluripotency }\end{array}$ & & & & & & \\
\hline \multirow{4}{*}{7} & \multirow{4}{*}{ GNA11(4) } & Axonal Guidance Signaling & \multirow{4}{*}{$\begin{array}{c}\text { guanine nucleotide binding } \\
\text { protein (G protein), alpha } 11 \\
\text { (Gq class) }\end{array}$} & \multirow{4}{*}{ ENSMUST00000043604 } & \multirow{4}{*}{2.433} & & & \\
\hline & & $\begin{array}{l}\text { Role of Macrophages, Fibroblasts } \\
\text { and Endothelial Cells in } \\
\text { Rheumatoid Arthritis }\end{array}$ & & & & $9.84 \mathrm{E}-03$ & $\begin{array}{c}\text { Plasma } \\
\text { Membrane }\end{array}$ & enzyme \\
\hline & & CXCR4 Signaling & & & & & & \\
\hline & & Inositol Phosphate Metabolism & & & & & & \\
\hline & & Role of IL-17A in Arthritis & & & & & & \\
\hline & & IL-17 Signaling & & & & & & \\
\hline 8 & $\begin{array}{l}\text { MAPKAPK2 } \\
(4)\end{array}$ & $\begin{array}{l}\text { Role of Macrophages, Fibroblasts } \\
\text { and Endothelial Cells in } \\
\text { Rheumatoid Arthritis }\end{array}$ & $\begin{array}{l}\text { mitogen-activated protein } \\
\text { kinase-activated protein } \\
\text { kinase } 2\end{array}$ & ENSMUST00000016672 & 1.991 & 7.62E-03 & Nucleus & kinase \\
\hline & & CD40 Signaling & & & & & & \\
\hline & & Role of IL-17A in Arthritis & & & & & & \\
\hline & & IL-17 Signaling & & & & & & \\
\hline 9 & $\operatorname{IL17RC(4)}$ & $\begin{array}{l}\text { Role of Macrophages, Fibroblasts } \\
\text { and Endothelial Cells in } \\
\text { Rheumatoid Arthritis }\end{array}$ & interleukin 17 receptor $\mathrm{C}$ & ENSMUST00000113062 & 3.053 & $1.21 \mathrm{E}-03$ & $\begin{array}{l}\text { Plasma } \\
\text { Membrane }\end{array}$ & $\begin{array}{l}\text { transmembrane } \\
\text { receptor }\end{array}$ \\
\hline & & IL-17A Signaling & & & & & & \\
\hline
\end{tabular}

Table 1. Important and representative genes altered in the fluorosis testicle based on the significant pathways of $100 \mathrm{mg} / \mathrm{l} \mathrm{NaF-treated} \mathrm{group.}$

Identification of Genes and Pathways Altered in Testicle. Analysis of the data indicated that there were 120 and 298 differentially expressed genes in the $50 \mathrm{mg} / \mathrm{l}$ and $100 \mathrm{mg} / \mathrm{l} \mathrm{NaF}$-treated groups, respectively. To further understand these changes at the pathway level, an IPA analysis was conducted and showed 99 and 246 genes mapped with corresponding GenBank, meanwhile, 19 and 33 signaling pathways to be significantly altered in the two treated groups separately (Fig. 1).

In the overview, a huge variety of the pathways with the different biological functions were identified by IPA in each treatment group. Study found that in the $50 \mathrm{mg} / \mathrm{l} \mathrm{NaF}$-treated group there was a significant influence on the communication signals between cells and cell biological mechanisms, related to the cellular growth, proliferation $\&$ development. However, it was noteworthy that 14 signaling pathways mainly focused on the immune responses in the $100 \mathrm{mg} / \mathrm{l} \mathrm{NaF-treated} \mathrm{group,} \mathrm{and} \mathrm{among} \mathrm{them} \mathrm{the} \mathrm{interleukin-17} \mathrm{(IL-17),} \mathrm{IL-17A} \mathrm{and} \mathrm{other} \mathrm{two} \mathrm{signaling}$ 

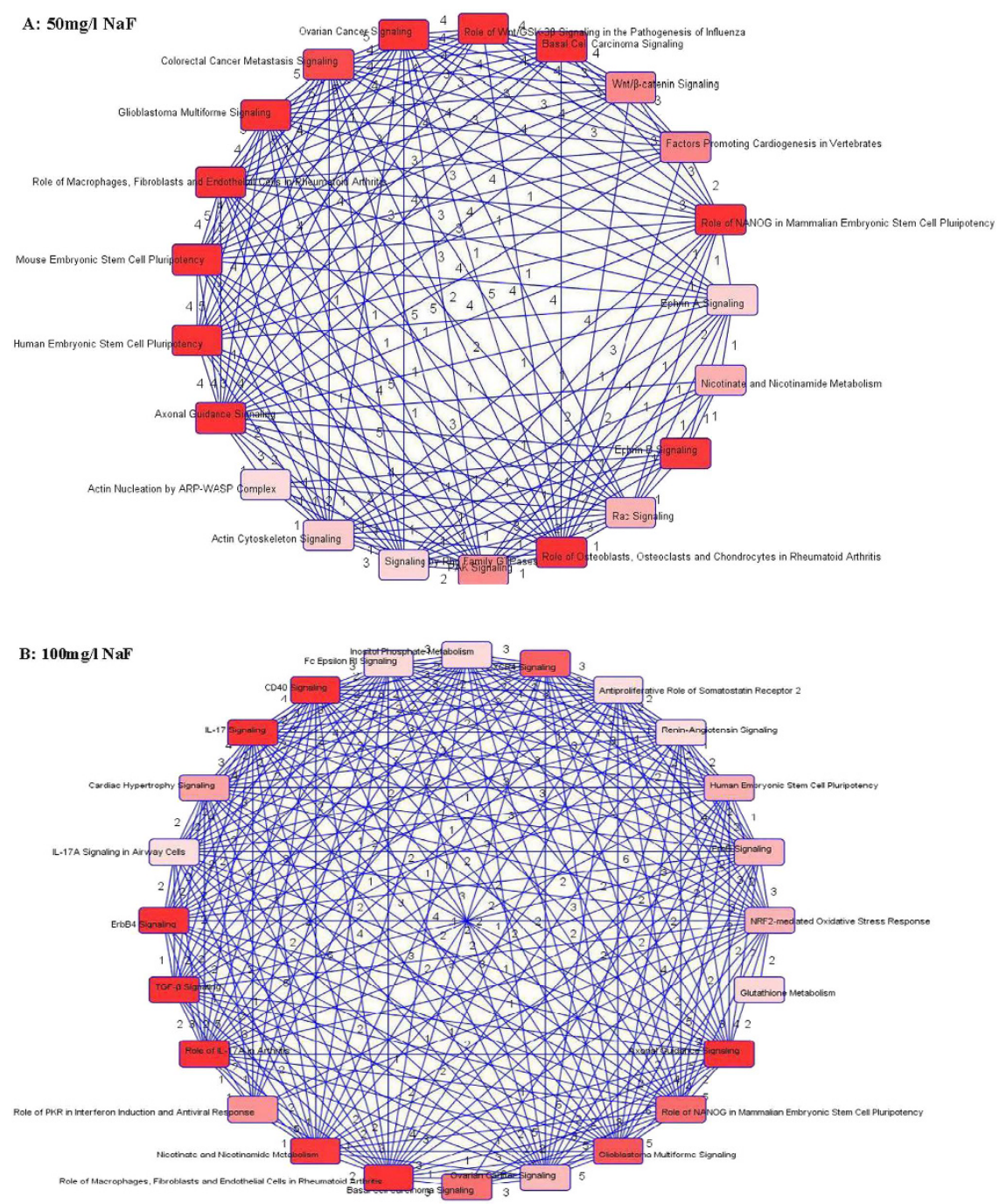

Figure 5. Detected interactions of enriched pathways in the testicle in the $50 \mathrm{mg} / \mathrm{l}$ and $100 \mathrm{mg} / \mathrm{l} \mathrm{NaF}$-treated groups. All significant pathways identified by IPA software were highly interrelated. The number represented the count of the common genes between two pathways.

transduction pathways presented the close association with the regulation of the IL-17 family and IL-17 receptors, which laid the foundation for validating the predicted genes.

There were 7 signaling pathways altered in both the NaF-treated groups as listed in Fig. 2. These signals were highly related with oxidative stress, cell development and cell apoptosis. Axonal Guidance Signaling and EphrinB Signaling pathway were associated with neurotransmission and altered in both the treatments.

In addition, for further information about the relationships between the differentially expressed genes and toxicology, 36 signaling pathways interacted in toxicity and were identified by IPA in the $100 \mathrm{mg} / \mathrm{l} \mathrm{NaF}$-treated group. Among them, four pathways were significantly altered, as listed in Fig. 3. Also four of them were highly relevant to cell differentiation and apoptosis as well as oxidative metabolism, including the transforming growth factor beta (TGF- $\beta$ ) signaling pathway, glutathione depletion reactions and NRF2-mediated oxidative stress response, especially the TGF- $\beta$ signaling pathway involved in many cellular processes and commonly inducing the production of cytokines.

Description of Important and Representative Genes in Testicle. In the perspective of gene functions, based on gene function annotation by IPA, 367 differentially expressed genes (DEGs) were screened both in the $50 \mathrm{mg} / \mathrm{l}$ and $100 \mathrm{mg} / \mathrm{l} \mathrm{NaF}$-treated groups when compared with the control group. All the genes were grouped into various functional categories, and the relationship among genes and functions, diseases were presented accurately. In Fig. 4, the percentage of genes that worked on the reproductive system development and function reached up to $12.26 \%$. About $10.90 \%$ and $7.08 \%$ were related to cell signaling and cellular growth and proliferation, respectively. More than $7.08 \%$ genes worked on skeletal and muscular disorders. Almost $56.38 \%$ genes were participating in the process of cell metabolism. It was found that the same gene may plays a different role in multiple metabolic processes. 


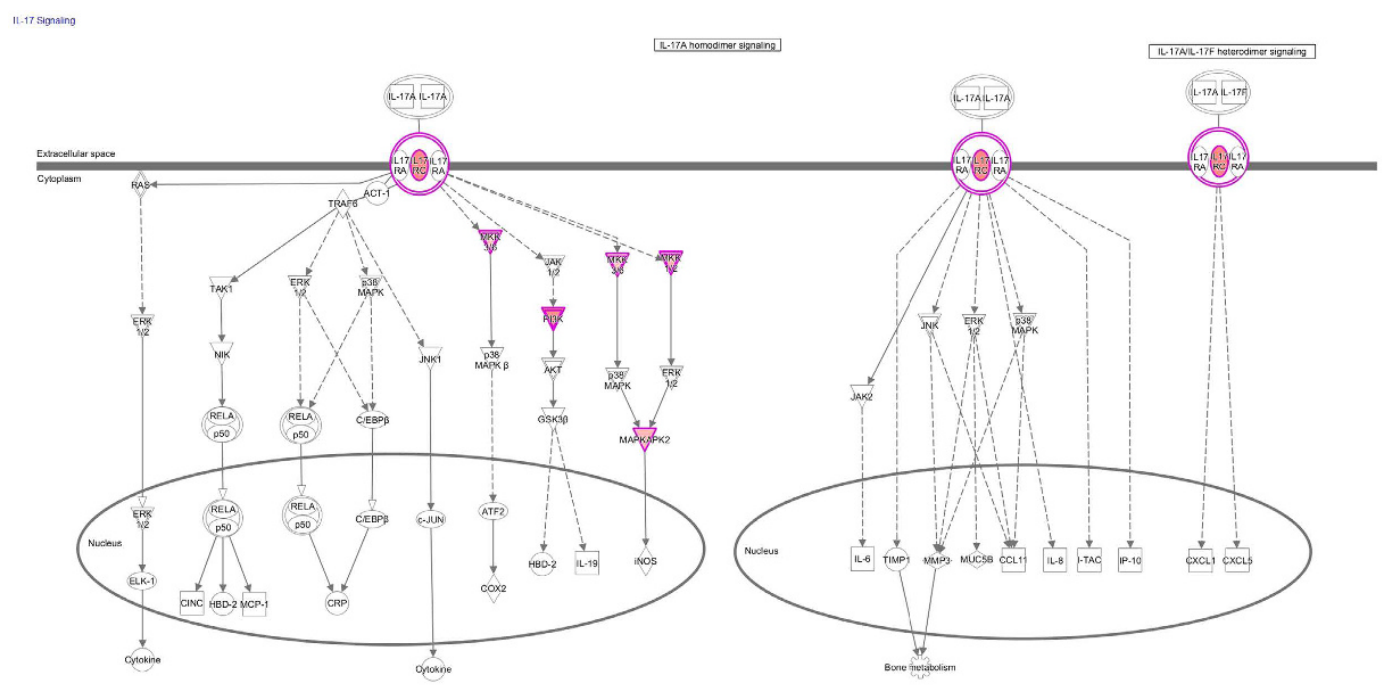

Figure 6. The map of the intracellular metabolic processes for IL-17 signaling pathway. The genes marked with red color indicated their value of genetic expression were significantly changed in the $100 \mathrm{mg} / \mathrm{l} \mathrm{NaF}$ group. MAP2K3/MAP2K6marked by MKK3/6, MAP2K1/MAP2K2 marked by MKK1/2, and PIK3R1 marked by PI3K.

In the perspective of pathways, shown in the Fig. 5, it has already suggested a correlation among the high-expression pathways identified by IPA software. These figures told us that many common genes were working on the regulation by the different signal pathways. Therefore, the interaction of multiple genes were concerned. Just as shown in the Table 1, in the testicle of mice treated with different fluoride concentrations, there were nine important and representative genes that appeared in more than four pathways, even MAP2K2 were directly involved in the regulation of almost 20 significant pathways. All of MAP2K2, PIK3R1, MAP2K3, MAPKAPK2 and IL17RC participated in the IL-17 intracellular metabolic processes (Fig. 6).

Expression Analysis by qRT-PCR. Based on the RNA-seq analysis of the pathways, nine genes, including IL17A, IL17RA, IL17RC, MAP2K3, MAP2K6, PIK3R1, MAPKAPK2, MAP2K1 and MAP2K2, representing the IL-17 signaling pathway described above were selected for confirmation as well as to monitor their expression with qRT-PCR, and the data was statistically analyzed as follows (Fig. 7).

Compared with control group, in the $100 \mathrm{mg} / \mathrm{l} \mathrm{NaF}$-treated group the mRNA expression level of IL17RA, IL17RC, MAP2K1, MAP2K2, MAP2K3 and MAPKAPK2 increased remarkably. The gene expression of MAP2K6 and $P I K 3 R 1$ reduced gradually. There was not significant changes in the gene expression of $50 \mathrm{mg} / \mathrm{l} \mathrm{NaF}$-treated group.

Besides that, the linear regression analysis of the fold change of the gene expression ratios between RNA-seq and qRT-PCR showed significantly positive correlation (Supplementary Fig. S1), confirming our transcriptome analysis.

\section{Discussion}

Although fluoride is safe and even healthy at low concentrations, sustained consumption of large amounts of soluble fluoride salts is dangerous. It was well known that toxic levels of fluoride exposure over a long period of time can adversely cause skeletal and tooth fluorosis induced by oxidative stress of osteoblasts and osteoclast ${ }^{34-36}$. It also can lead to some adverse effects on a number of physiological functions, for example, thyroid dysfunction ${ }^{37}$, nephrotoxicity ${ }^{35,38}$, cardiometabolic risk ${ }^{39,40}$, neurodevelopmental disorder in juvenile stage ${ }^{38,41,42}$ and even male reproductive endocrine disruption ${ }^{7,8}$.

However, the mechanisms of reproduction injury induced by taking in excess fluoride were still inconclusive. Attempting to address the root cause, this experiment was the first time using the transcriptome sequencing in the testicle of experimental fluorosis mice to explore the relative gene expression levels in mouse testis and interpret the effect of fluoride poisoning in the male reproductive system. Different from earlier studies, our study considered the damages of fluoride on the male reproductive system holistically, including a variety of pathways and genes, rather than just a single factor.

Generally, the testis and the capacity of sperm were of the important indices for evaluating the reproductive system. The testis comprises mostly seminiferous tubules and interstitial cells, localized between seminiferous tubules, to produce and secrete testosterone ${ }^{43}$. The epithelium of the tubule consists of a type of sustentacular cells known as Sertoli cells, which differentiate through meiosis into sperm cells. During spermatogenesis, the main function of Sertoli cells is to nourish the developing sperm cells and also act as phagocytes, consuming the residual cytoplasm and secreting the inhibin, activins and androgen binding protein ${ }^{44}$. While our previous studies reported that the pathologic and morphological changes of chronic fluorosis in testicles and sperm were observed. The cavitation of seminiferous tubules, cellular atrophy and other structural damages can result in the reduction of androgen 
|L-17A

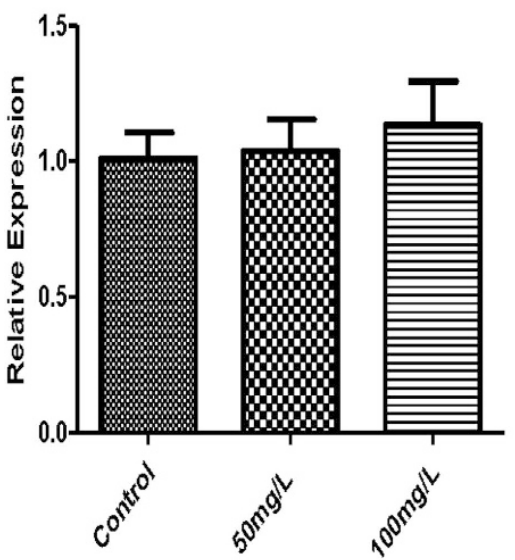

MAP2K1

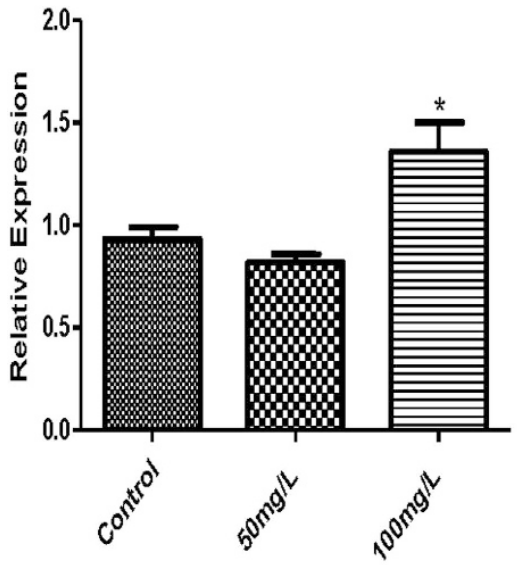

MAP2K6

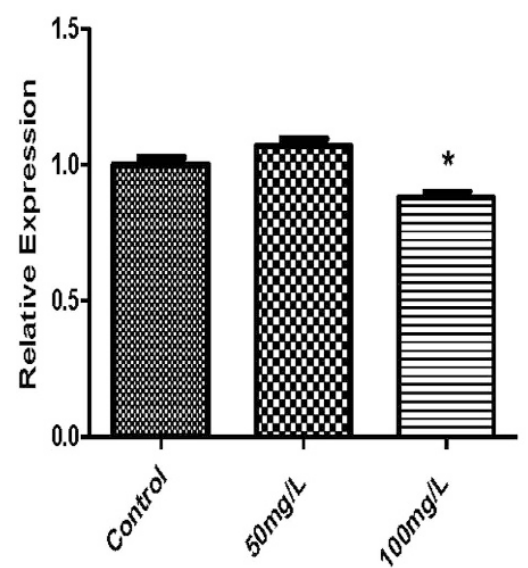

IL-17RA

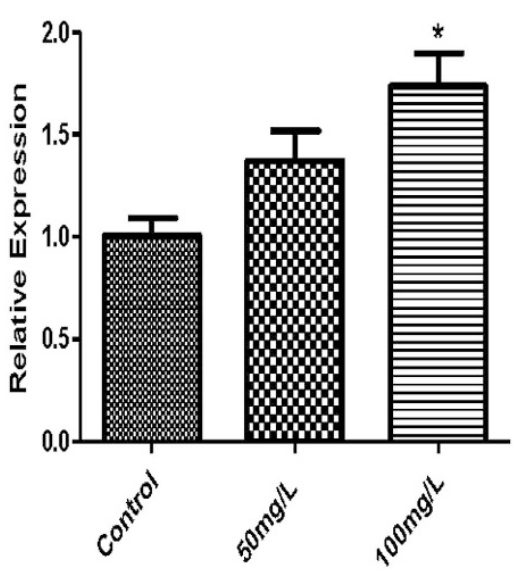

MAP2K2

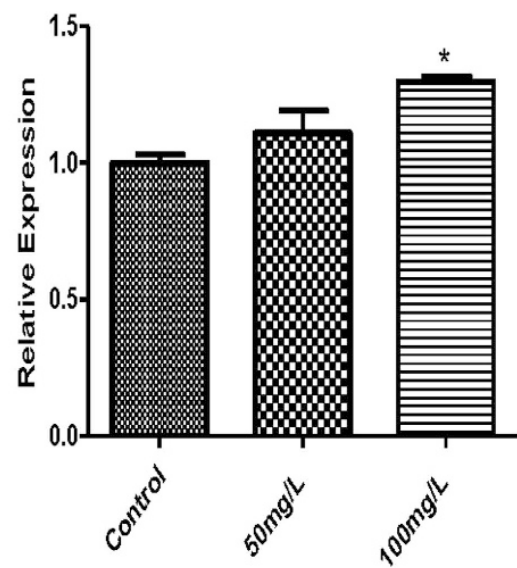

MAPKAPK2

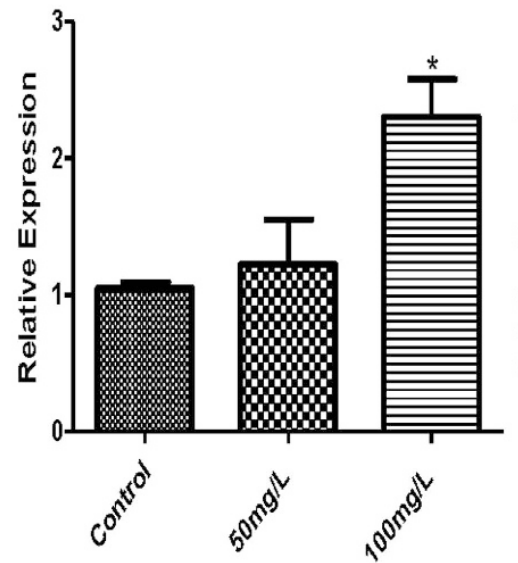

IL-17RC

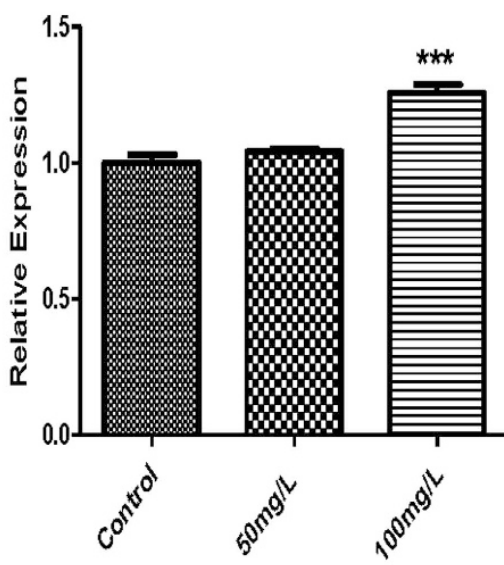

MAP2K3

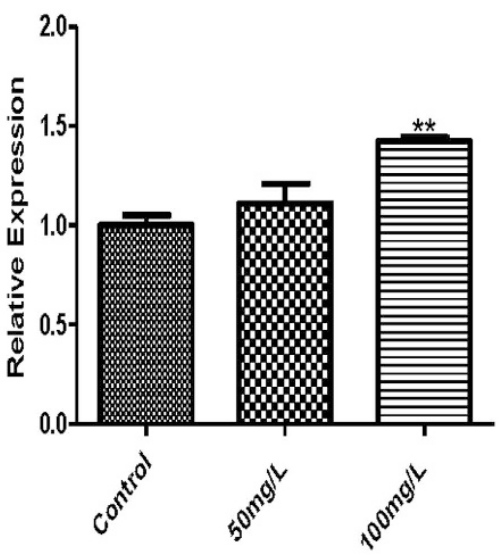

PIK3R1

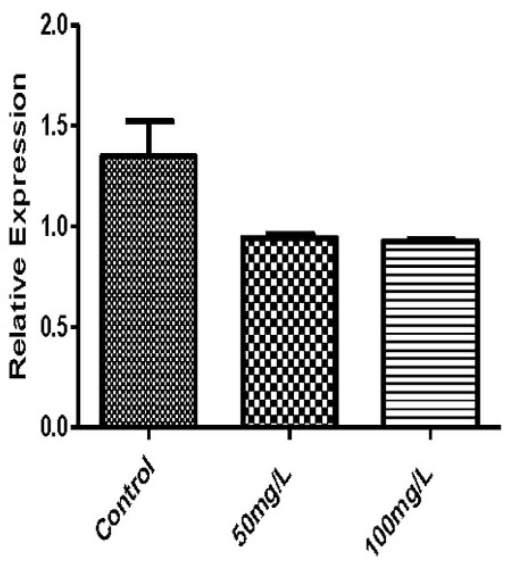

Figure 7. Results of the nine mRNA expression related to the IL-17 signaling pathway in testis of mice in each treatment group. Compared with the control group, ${ }^{\star} P<0.05,{ }^{\star \star} P<0.01,{ }^{\star * \star} P<0.001, \mathrm{n}=5$. 
distention and vesiculization of smooth endoplasmic reticulum and the deposition of large lipid droplets appearing in the Sertoli cells under the ultrastructural observations of rat testes. So what happened in these cells?

Mendoza-Schulz A. et al. ${ }^{46}$ said that fluoride had significantly effect on hormone secretion and protein synthesis in the endocrine cells. They found the changes in phosphorylation status of both cytoskeletal and cytosolic protein fractions, as well as in actin cytoskeletal arrangements were observed. Similarly, in our research of the $50 \mathrm{mg} / \mathrm{l} \mathrm{NaF}$-treated group, actin nucleation and actin cytoskeleton signal pathways were stimulated with the significant expression of growth factors. In response to these microenvironmental and functional alterations, immune cells often represent dramatically change their functional activities to reprogram their cellular metabolism and release the metabolic stresses ${ }^{47}$. A lymphocyte, such as $\mathrm{T}$ cells, transforms from a relatively inert cell to a cell engaging in robust growth and proliferation, often producing large amounts of effector molecules, including cytokines $^{47}$. Yet despite all that, there is emerging evidence that metabolic enzymes and regulators can also have a direct role in controlling immune cell functions ${ }^{47}$. For instance, in CD4 T cells, GAPDH has been described to bind to IL2 mRNA and inhibit translation. Accordingly, the testicular immunological efficiency was enhanced along with the increase of doses of fluoride.

Although the testis is an immune privileged organ and the most important spaces of spermatogenesis and steroidgenesis, toxic agents and inflammation may overwhelm immune suppressor mechanisms inducing autoimmune reactions against spermatic antigens which result in aspermatogenesis and infertility ${ }^{18}$. The cytokine interleukin-17, ukin-17 (IL-17 or IL-17A) and the pathology associated with aberrant IL-17 signaling played an important role in maintaining the testicular immune including cell immunity, mucosal immunity and cytokines, especially in experimental autoimmune orchitis (EAO) ${ }^{18,48,49}$. Jacobo P. et al. ${ }^{49}$ reported that in EAO testis developed by active immunization with spermatic antigens, testis-infiltrating cells revealed an increased number of macrophages, dendritic cells and T cell subsets including Th17 cells so that TNF- $\alpha$, IL-17 and other immune cells secreted pro-inflammatory cytokines, which disrupted the normal testicular immune suppressor microenvironment. And they said IL-17 cells in EAO testis have a mature immunogenic status and are able to induce immune responses to testicular antigens.

In many cases, an excess of IL-17 is associated with abnormal inflammation, implicated in rheumatoid arthritis, asthma, psoriatic arthritis, ankylosing spondylitis, systemic lupus erythematosus and autoimmune encephalomyelopathy, which, not surprisingly, have become a major therapeutic target for these diseases. It have been recently found Th17 cells are a subset of T helper cells and play important functions in host defense and the pathogenesis of various human autoimmune and inflammatory diseases ${ }^{50-52}$. Th 17 cells could produce IL-17A, who would mediate many of the downstream pathologic functions in the cells. IL-17A utilizes IL-17RA and IL-17RC as its receptors that are mainly expressed on tissue epithelial cells and fibroblasts. While IL-17A is important for host defense against many extracellular pathogens, they can also cause excessive tissue damage and exacerbate proinflammatory responses during autoimmunity ${ }^{52}$. Therefore, as for our study, the IL-17 signal pathway and its proinflammatory cytokines were expressed in higher levels in high fluoride-exposed testis $(100 \mathrm{mg} / \mathrm{l} \mathrm{NaF})$. It was the response to the invasion of the immune system by extracellular fluoride and involve in the maintenance of testicular immune privilege and spermatogenesis ${ }^{53}$. And the activation of toll-like receptors IL-17RA and IL-17RC suggested that these cells played important roles in protecting the seminiferous epithelium from invading fluoride.

During this study we also found the transforming growth factor beta (TGF- $\beta$ ) signaling pathway has the most important research value in the toxicology field. TGF- $\beta$ signaling pathway is involved in many cellular processes in both the adult organism and the developing embryo including cell growth, cell differentiation, apoptosis, cellular homeostasis and other cellular functions ${ }^{54-56}$. TGF- $\beta$ s belong to a family of the immunosuppressive and anti-inflammatory TGF superfamily and widely distributed in embryonic and adult tissues ${ }^{18}$. Most TGF- $\beta$ s are present in the testis as the latent inactive precursor form and are expressed constitutively at high levels being produced mainly by Sertoli cells, Leydig cells, and peritubular, but in post pubertal testis, cytokines of the TGF- $\beta$ family are also expressed by early spermatids and spermatocytes. Once activated at its site of action by local proteases, TGF- $\beta$ s would contribute to the immunological privileged site of the testis through their strong immunosuppressive ability ${ }^{18,52}$. Thus, what we think is that the gene activation of TGF- $\beta$ family have help to sustain the immune exemption of testicle in fluorosis.

In addition, based on the expression of $M K K 3 / 6, M K K 1 / 2$ and $P I 3 K$ in RNA-seq and the intracellular metabolic processes of IL-17 signaling pathway, we could infer that the IL-17 family members took part in the activation of the Mitogen-activated protein (MAP) kinase pathway and PI3 Kinase-AKT pathway, which are involved in the regulation of a variety of growth and differentiation pathways through several phosphorylation cascades ${ }^{52,57}$. The MAP signaling cascade is activated by a number of receptors: the extracellular mitogen binds to the membrane receptor, then this allows Ras (a GTPase) to swap its GDP for a GTP, and activate MAP3K, which activates MAP2K, which activates MAPK, finally MAPK can activate a transcription factor ${ }^{58,59}$. MAPK-ERK1/2 played an important role in the regulation of cell growth and cell cycle progression. PI3-kinase and its downstream kinase AKT are potent inhibitors of apoptosis in many cell types. AKT is phosphorylated upon IL-17stimulation and also adds to the possible involvement of PI3-kinase in the propagation of signal through the IL-17R ${ }^{52}$. Together, these results indicated that PI3-kinase/AKT and MAPKs serves as the upstream arbitrator of the IL-17 pathway activation and had contributed to the increased binding of the inflammatory transcription factor in IL-17 pathways.

Anyway, all the found helped us to better understand the molecular basis of reproduction and sperm metabolism disorder and deeply identify the mechanisms involved in reproductive toxicity and other pathological disorders associated with fluoride. At first, the aim we were pursuing was to find really reliable molecules and genes associated with reproduction by RNA direct sequencing of testis. However, what we got was quite surprising: a plenty of other metabolic pathways and classic genes of the systemic and comprehensive responses were dig out. Peeping a spot to see overall picture: local delicate change was packed with the complex issues of the whole 
organism. But for the further verification and exploration, researches on the cellular level and the significant expression of proteins during the spermatogenesis should be carried out.

\section{Conclusions}

The high expression of genes in the IL-17 signal pathway was the response to the invasion of the testicular immune system by extracellular fluoride. The cytokines of the TGF- $\beta$ family performed key roles in the maintenance of immune privilege and spermatogenesis. Meanwhile, PI3-kinase/AKT and MAPKs acted as the upstream arbitrator of the IL-17 pathway activation and have contributed to the increased binding of the inflammatory transcription factor in IL-17 pathways.

All the findings, including the metabolic pathways and classic genes, could provide new ideas and clues for further researches of the molecular mechanism of fluorosis on the field of reproduction and development, immune response, oxidative stress, cell regulation mechanism and so on.

\section{References}

1. Elbetieha, A., Darmani, H. \& Al-hiyasat, A. S. Fertility effect of Sodium fluoride in male mice. Fluoride. 33, 128-134 (2000).

2. Freni, S. C. Exposure to high fluoride concentrations in drinking water is associated with decreased birth rates. Journal of Toxicology and Environmental Health, Part A Current Issues. 42, 109-121 (1994).

3. Izquierdo-vega, J. A., Manuel, S. G. \& Luz maría, D. R. Decreased in vitro fertility in male rats exposed to fluoride-induced oxidative stress damage and mitochondrial transmembrane potential loss. Toxicology \& Applied Pharmacology. 230, 352-357 (2008).

4. Jin, K. et al. Effect of Sodium fluoride on male mouse fertility $\dagger$. Andrology. 3, 544-551 (2015).

5. Ortiz, P. D. et al. Fluoride-induced disruption of reproductive hormones in men. Environ Res. 93, 20-30 (2003).

6. Soetan, K. O., Olaiya, C. O. \& Oyewole, O. E. The importance of mineral elements for humans, domestic animals and plants: A review. African Journal of Food Science. 4, 200-222 (2010).

7. Spittle, B. \& Zealand, N. D. Fluoride and fertility. Fluoride. 41, 98-100 (2008).

8. Spittle, B. Halting the inertia of indifference: fluoride and fertility revisited. Fluoride. 42, 159-161 (2009).

9. Han, H. et al. Fluoride exposure changed the structure and the expressions of reproductive related genes in the hypothalamuspituitary-testicular axis of male mice. Chemosphere. 135, 297-303 (2015).

10. Huang, C., Niu, R., Wang, J. \& China, S. Toxic effects of Sodium fluoride on reproductive function in male mice. Fluoride. 40, 162-168 (2007)

11. Wan, S., Zhang, J., Wang, J. \& Shanxi, B. Effects of high fluoride on sperm quality and testicular histology in male rats. Fluoride. 39, 17-21 (2006).

12. Zhang, J., Chen, L., Ma, J., Zhou, B. \& Wang, J. China Effects of Sodium fluoride and Sulfur dioxide on oxidative stress and antioxidant defenses in rat testes. Fluoride. 39, 185-190 (2006).

13. Sun, Z., Wang, B., Niu, R., Zhang, J. \& Wang, J. Decreased sperm hyperactivation and low Catsper1 expression in mice exposed to fluoride. Fluoride. 42, 167-173 (2009).

14. Sun, Z. et al. Effects of Sodium fluoride on hyperactivation and $\mathrm{Ca}^{2+}$ signaling pathway in sperm from mice: an in vivo study. Arch Toxicol. 84, 353-361 (2010).

15. Lu, Z., Wang, S., Sun, Z., Niu, R. \& Wang, J. In vivo influence of Sodium fluoride on sperm chemotaxis in male mice. Arch Toxicol. 88, 533-539 (2014).

16. Sun, Z. et al. Fluoride decreased the sperm ATP of mice through inhabiting mitochondrial respiration. Chemosphere. 144, 1012-1017 (2016).

17. Diemer, T., Hales, D. B. \& Weidner, W. Immune-endocrine interactions and Leydig cell function: the role of cytokines. Andrologia. 35, 55-63 (2003).

18. Guazzone, V. A., Jacobo, P., Theas, M. S. \& Lustig, L. Cytokines and chemokines in testicular inflammation: a brief review. Microsc Res Tech. 72, 620-628 (2009).

19. Jacobo, P., Guazzone, V. A., Theas, M. S. \& Lustig, L. Testicular autoimmunity. Autoimmun Rev. 10, 201-204 (2011).

20. Krasowska, A., Włostowski, T. \& Bonda, E. Zinc protection from fluoride-induced testicular injury in the bank vole (Clethrionomys glareolus). Toxicol Lett. 147, 229-235 (2004).

21. Lampiao, F. \& Du plessis, S. S. TNF- $\alpha$ and IL-6 affect human sperm function by elevating nitric oxide production. Reprod Biomed Online. 17, 628-631 (2008).

22. Wang, J. et al. Toxic effects of fluoride on reproductive ability in male rats: sperm motility, oxidative stress, cell cycle, and testicular apoptosis. Fluoride. 42, 174-178 (2009).

23. Maher, C. A. et al. Transcriptome sequencing to detect gene fusions in Cancer. Nature. 458, 97-101 (2009).

24. Yang, Z., Bruno, D. P., Martens, C. A., Porcella, S. F. \& Moss, B. Simultaneous high-resolution analysis of vaccinia virus and host cell transcriptomes by deep RNA sequencing. Proceedings of the National Academy of Sciences. 107, 11513-11518 (2010).

25. Ramskold, D., Wang, E. T., Burge, C. B. \& Sandberg, R. An abundance of ubiquitously expressed genes revealed by tissue transcriptome sequence data. PLoS Comput Biol. 5, e1000598 (2009).

26. Barbier, O., Arreola-mendoza, L. \& Del razo, L. M. Molecular mechanisms of fluoride toxicity. Chem Biol Interact. 188, 319-333 (2010).

27. Long, H. et al. Fluoride toxicity in the male reproductive system. Fluoride. 42, 260-276 (2009).

28. Zhang, S. et al. Fluoride-elicited developmental testicular toxicity in rats: Roles of endoplasmic reticulum stress and inflammatory response. Toxicol Appl Pharmacol. 271, 206-215 (2013).

29. Cao, J. et al. RNA deep sequencing analysis reveals that nicotine restores impaired gene expression by viral proteins in the brains of HIV-1 transgenic rats. PLoS One. 8, e68517 (2013).

30. Li, M. et al. Transcriptome sequencing of gene expression in the brain of the HIV-1 transgenic rat. PLoS One. 8, e59582 (2013).

31. Cameron, C. M. et al. Gene expression analysis of host innate immune responses during Lethal H5N1 infection in ferrets. $J$ Virol. 82, 11308-11317 (2008).

32. Jiménez-marín, Á., Collado-romero, M., Ramirez-boo, M., Arce, C. \& Garrido, J. J. Biological pathway analysis by ArrayUnlock and ingenuity pathway analysis. S6 (BioMed Central Ltd, 2009).

33. Krämer, A., Green, J., Pollard, J. \& Tugendreich, S. Causal analysis approaches in ingenuity pathway analysis (ipa). Bioinformatics $703-710$ (2013)

34. Allen, K. C., Sanchez, C. J., Niece, K. L., Wenke, J. C. \& Akers, K. S. Voriconazole enhances the osteogenic activity of human osteoblasts in vitro through a Fluoride-Independent mechanism. Antimicrob Agents Chemother. 59, 7205-7213 (2015).

35. Huo, M. et al. Effects of different CA levels on functional injury of kidneys induced by fluoride in rat. Chinese Journal of Animal and Veterinary Sciences. 9, 1483-1490 (2012).

36. Wang, J. et al. Effects of protein and Calcium supplementation on bone metabolism and thyroid function in protein and Calcium deficient rabbits exposed to fluoride. Fluoride. 41, 307-315 (2008). 
37. Sachdeva, S., Ahmed, J. \& Singh, B. Thyroid dysfunction associated with excess fluoride intakes: Scope for primary prevention. Thyroid Research and Practice. 12, 50-56 (2015).

38. Choi, A. L., Grandjean, P., Sun, G. \& Zhang, Y. Developmental fluoride neurotoxicity: Choi et al. Respond. Environ Health Perspect. 121, a70 (2013)

39. Nabavi, S. M., Nabavi, S. F., Moghaddam, A. H., Setzer, W. N. \& Mirzaei, M. Effect of silymarin on Sodium fluoride-induced toxicity and oxidative stress in rat cardiac tissues. Anais da Academia Brasileira de Ciências. 84, 1121-1126 (2012).

40. Yan, X. et al. Sodium fluoride induces apoptosis and alters the cardiac arrest rate in primary cardiomyocytes. Fluoride. 48, 234-240 (2015).

41. Malin, A. J. \& Till, C. Exposure to fluoridated water and attention deficit hyperactivity disorder prevalence among children and adolescents in the United States: an ecological association. Environmental Health. 14, 17-26 (2015).

42. Rahim, Z. H., Bakri, M. M., Zakir, H. M., Ahmed, I. A. \& Zulkifli, N. A. High fluoride and low pH level have been detected in popular flavoured beverages in Malaysia. Pakistan journal of medical sciences. 30, 404-408 (2014).

43. Skinner, M. K., Mclachlan, R. I. \& Bremner, W. J. Stimulation of sertoli cell inhibin secretion by the testicular paracrine factor pmods. Molecular \& Cellular Endocrinology. 66, 239-249 (1989).

44. Luís, R. et al. Metabolic regulation is important for spermatogenesis. Nat Rev Urol. 9, 330-338 (2012).

45. Song, K. Studies on ultrastructures of lactotrophs of lactating rats during chronic fluorosis. Chinese Journal of Endemiology 6 , 321-323 (1990).

46. García-montalvo, E. A., Reyes-pérez, H. \& Razo, L. D. Fluoride exposure impairs glucose tolerance via decreased insulin expression and oxidative stress. Toxicology. 263, 75-83 (2009).

47. Loftus, R. M. \& Finlay, D. K. Immunometabolism; cellular metabolism turns immune regulator. Journal of Biological Chemistry. 291, $1-10$ (2015).

48. Garrett-sinha, L. A., John, S. \& Gaffen, S. L. IL-17 and the Th17 lineage in systemic lupus erythematosus. Curr Opin Rheumatol. 20, 519-525 (2008).

49. Jacobo, P., Pérez, C. V., Theas, M. S., Guazzone, V. A. \& Lustig, L. $\mathrm{CD}^{4+}$ and $\mathrm{CD}^{8+} \mathrm{T}$ cells producing Th1 and Th17 cytokines are involved in the pathogenesis of autoimmune orchitis. Reproduction. 141, 249-258 (2011).

50. Hu, Y., Shen, F., Crellin, N. K. \& Ouyang, W. The IL-17 pathway as a major therapeutic target in autoimmune diseases. Ann N Y Acad Sci. 1217, 60-76 (2011)

51. Huppler, A. R., Bishu, S. \& Gaffen, S. L. Mucocutaneous candidiasis: the IL-17 pathway and implications for targeted immunotherapy. Target. 14, 217-225 (2012).

52. Hwang, S. et al. IL-17 induces production of IL-6 and IL-8 in rheumatoid arthritis synovial fibroblasts via NF-kappaB-and PI3kinase/Akt-dependent pathways. Arthritis Res Ther. 6, R120-R128 (2004).

53. Qu, N. et al. Pivotal roles of T-helper 17-related cytokines, IL-17, IL-22, and IL-23, in inflammatory diseases. Clinical and Developmental Immunology. 2013, 293-306 (2013).

54. Estelle, B. et al. Reciprocal developmental pathways for the Generation of pathogenic effector TH17 and regulatory T cells. Nature. 441, 235-238 (2006).

55. Mangan, P. R. et al. Transforming growth factor-beta induces development of the T (H)17 lineage. Nature. 441, 231-234 (2006).

56. Veldhoen, M., Hocking, R. J., Atkins, C. J., Locksley, R. M. \& Stockinger, B. TGFbeta in the context of an inflammatory cytokine milieu supports de novo differentiation of IL-17-producing T cells. Immunity. 24, 179-189 (2006).

57. Mio, K., Fumio, K., Junichi, F., Shau-ku, H. \& Nobuyuki, H. Role of interleukin-17F in asthma. Inflamm Allergy Drug Targets. 8, 383-389 (2009)

58. Schulze, W. X., Deng, L. \& Mann, M. Phosphotyrosine interactome of the ErbB-receptor kinase family. Mol Syst Biol. 1, 2005.0008-2005.0008 (2005)

59. Seger, R. \& Krebs, E. G. The MAPK signaling cascade. Faseb Journal Official Publication of the Federation of American Societies for Experimental Biology. 9, 726-735 (1995).

\section{Acknowledgements}

Supported by National Natural Science Foundation of China (Grant Nos 31172376 and 31372497, 31540061). Thank University of Virginia for offering a powerful bioinformatics platform for our study. Thank Dr. Wang Jundong and Dr. Li Mingding for providing a visiting scholar opportunity to Meijun Huo.

\section{Author Contributions}

J.W., S.W. and Z.S. designed the study and contributed funding. H.H. and Z.L. collected samples and processed samples. S.W., M.H. and X.Y. completed RNA sequencing and statistical analyses. M.H. and S.W. contributed to writing the manuscript. All authors discussed the results and commented on the manuscript.

\section{Additional Information}

Supplementary information accompanies this paper at http://www.nature.com/srep

Competing financial interests: The authors declare no competing financial interests.

How to cite this article: Huo, M. et al. Role of IL-17 Pathways in Immune Privilege: A RNA Deep Sequencing Analysis of the Mice Testis Exposure to Fluoride. Sci. Rep. 6, 32173; doi: 10.1038/srep32173 (2016).

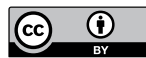

This work is licensed under a Creative Commons Attribution 4.0 International License. The images or other third party material in this article are included in the article's Creative Commons license, unless indicated otherwise in the credit line; if the material is not included under the Creative Commons license, users will need to obtain permission from the license holder to reproduce the material. To view a copy of this license, visit http://creativecommons.org/licenses/by/4.0/

(c) The Author(s) 2016 